\title{
Analisis Pengukuran Usability Pada Situs Badan Pusat Statistik Provinsi Sumatera Selatan Dengan Menggunakan Metode Webuse
}

\author{
Ali Abdul Jabbar Ibnurozi¹, Rusmala Santi², Catur Eri Gunawan³ \\ 1,2,3Sistem Informasi, Fakultas Sains dan Teknologi, UIN Raden Fatah Palembang \\ Email: aliaja18495@gmail.com¹, rusmalasanti_uin@radenfatah.ac.id², caturerig@radenfatah.ac.id³
}

\begin{abstract}
The Central Statistics Agency of South Sumatra Province has an official website that provides information about the census. This BPS website can be accessed by users who want to find data about the census. However, this site still has several problems, both in terms of interface appearance and ease of use. This research aims to measure the ease of use of the website of the Central Statistics Agency of South Sumatra Province by conducting a usability test using the Webuse method. This study used a sample of 96 respondents using the Lameshow formula. The data collection method used is by distributing questionnaires both offline and online. The results of this study indicate that each variable has a good usability level. With the content, organization, and readability variables having a value of 0.76 , the navigation and links variable having a value of 0.75 , the user interface design variable having a value of 0.76 , and the performance and effectiveness variable having a value of 0.77 . So it can be concluded that the website of the Central Statistics Agency of South Sumatra has a good level of usability according to the results of the study, which obtained data from 96 different respondents as the sample.
\end{abstract}

Keywords: Usability, webuse, website, cantral statistic agency

\section{PENDAHULUAN}

Dalam pengembangan suatu sistem perlu memperhatikan kepuasan dari pengguna, baik dari tingkat kesukaan pengguna, pemahaman pengguna akan produk, dan kegunaan dari produk itu sendiri. Suatu sistem tidak hanya harus mempunyai fungsi yang bagus namun juga yang mempunyai desain yang bagus sudah dapat memuaskan pengguna. Namun saat ini hal tersebut belum cukup karena pengguna membutuhkan pengalaman yang menyenangkan saat menggunakan tersebut tersebut. Usability merupakan salah satu poin yang sangat menentukan dalam pembangunan sebuah sistem. Karena usability merupakan sebuah atribut kualitas yang dapat menilai seberapa mudah interface atau antar muka digunakan. 
Ada beberapa metode yang bisa digunakan untuk mengevaluasi usability sebuah sistem. Diantaranya yaitu Heuristic Evaluation (HE), Cognitive Walkthrough (CW), Think - Aloud Evaluation (TA) dan juga Website Usability Evaluation (Webuse). Diantara metode-metode tersebut penulis memilih metode Webuse karena metode ini dapat melakukan evaluasi usability semua jenis website dengan berfokus pada sistem evaluasi yang terdiri dari 24 pertanyaan untuk mengevaluasi usability situs atau website tersebut. Badan Pusat Statistik memiliki sebuah situs resmi yang bisa dikases oleh para pengunjung. Situs ini memuat informasi seputar hasil sensus, baik itu sensus ekonomi, sesnsus pertanian dan sensus lainnya. Namun didalam penerapan situs ini masih ada beberapa hal yang menjadi keluhan dari pengguna, baik itu dalam segi tampilan antarmuka, kemudahan dalam penggunaannya, dan kemudahan dalam mengakses situs tersebut. Permasalahan-permasalahan tersebut secara tidak langsung akan mempengaruhi kualitas dari situs BPS itu sendiri. Karena dengan adanya permasalahan tersebut akan membuat pengguna situs menjadi kurang tertarik untuk mengakses situs itu kembali.

Berdasarkan permasalahan tersebut maka penulis mengambil topik penelitian untuk mengukur usability pada Situs Badan Pusat Statistik Provinsi dengan menggunakan metode Webuse. Metode Webuse digunakan untuk mengevaluasi website atau situs berfokus pada sistem evaluasi berbasis web yang terdiri dari 24 pertanyaan untuk mengevaluasi usability dari situs tersebut. Oleh karena itu permasalahan mengenai Analisis Pengukuran usability pada Situs Badan Pusat Statistik Menggunakan Metode Webuse akan dikaji dalam penelitian ini.

\section{METODOLOGI PENELITIAN}

Penelitian ini menggunakan metode Webuse, dimana metode Webuse digunakan untuk mengevaluasi usability website dengan alat analisis data menggunakan statistik deskriptif. Oleh karena itulah dalam penelitian ini metode yang digunakan yaitu metode deskriptif dengan menggunakan data kualitatif. Pengertian deskriptif menurut Sugiyono (2012: 29) adalah metode yang berfungsi untuk mendeskripsikan atau memberi gambaran terhadap objek yang akan diteliti, melalui data atau sampel yang telah dikumpulkan, tanpa melakukan analisis dan membuat kesimpulan yang berlaku umum.

\subsection{Usability}

Usability dapat didefinisikan sebagai kualitas kemampuan sebuah perangkat lunak untuk membantu penggunanya menyelesaikan sebuah tugas. Sejauh mana sistem dapat digunakan pengguna untuk mencapai tujuan tertentu, dalam konteks dan tingkat tertentu (International Standards Office, 2010). Sedangkan 
menurut Pressman (2012) usability yaitu tingkatan kemampuan antarmuka aplikasi dapat digunakan untuk mempermudah pengguna aplikasi tersebut.

Jakob Nielsen dalam Larasati (2010) mengemukakan 5 buah atribut Usability untuk menentukan kualitas dari sebuah sistem, yaitu:

1) Learnability, yaitu seberapa mudah bagi pengguna memahami saat pertama kali melihat atau menggunakan.

2) Efficiency, yaitu seberapa cepat dapat menyelesaikan perintah (input).

3) Memorability, yaitu saat pengguna menggunakan lagi seberapa ingat (terbiasa) terhadap penggunaannya.

4) Errors, yaitu berapa banyak kesalahan yang dibuat ketika digunakan.

5) Satisfaction, yaitu seberapa nyaman dan kepuasan pengguna dalam menggunakan situs tersebut.

\subsection{Website Usability Evaluation (Webuse)}

Web Usability Evaluation atau Webuse digunakan untuk mengevaluasi usability website yang terdiri dari 24 pertanyaan dengan 5 opsi jawaban yang terbagi dalam 4 kategori. Metode Webuse dapat melakukan evaluasi usability semua jenis website dan domain. Alat analisis data menggunakan statistik deskriptif. Metode Webuse tersusun dalam 4 kategori yaitu, (1) Content, organization, and readability, (2) Navigation and links, (3) User interface design, dan (4) Performance and effectiveness (Chiew \& Salim, 2003). Berikut ini adalah evaluasi usability dengan menggunakan metode Webuse:

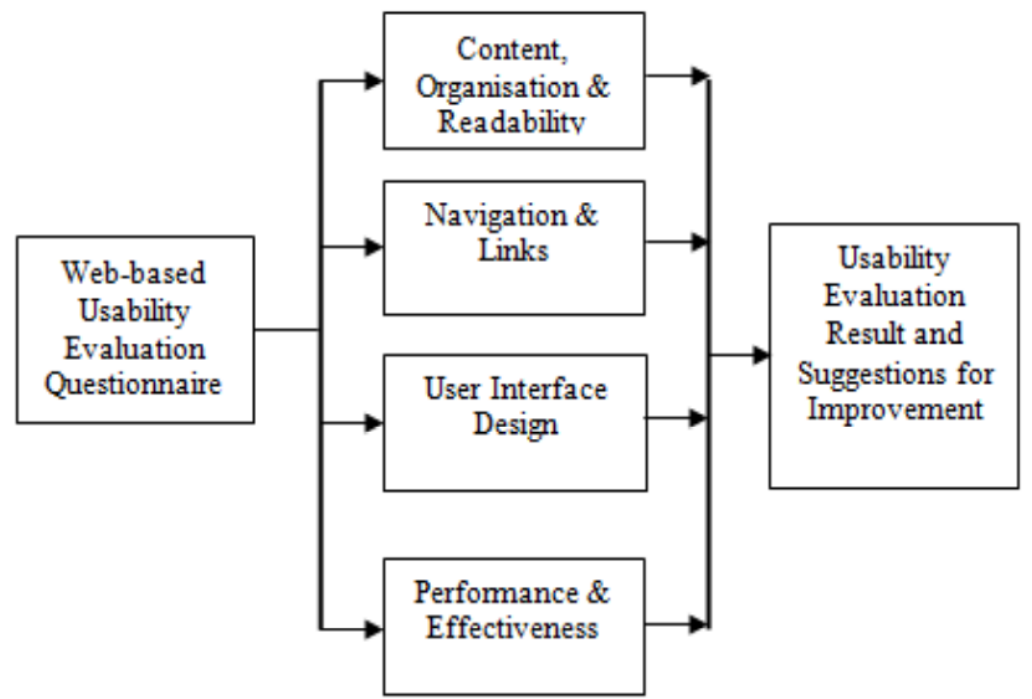

Gambar 1 Evaluasi dengan metode Webuse (Chiew dan Salim, 2003) 
Dari gambar diatas terlihat bahwa Webuse dapat mengevaluasi usability pada website dengan cara meminta pengguna untuk mengevaluasi situs. Dengan menggunakan metode evaluasi berbasis web yang memungkinkan pengguna untuk memberikan tanggapan dari aspek usability pada website yang akan dievaluasi (Chiew dan Salim, 2003).

\subsection{Populasi dan Sampel}

\subsubsection{Populasi}

Menurut Sugiyono (2017:80) populasi adalah wilayah generalisasi yang terdiri atas objek atau subjek yang mempunyai kualitas dan karakteristik tertentu yang ditetapkan oleh peneliti untuk dipelajari dan kemudian ditarik kesimpulannya. Sedangkan menurut Thoifah (2016:14) Populasi merupakan seluruh karakteristik yang menjadi objek penelitian, dimana karakteristik tersebut berkaitan dengan seluruh kelompok orang, peristiwa, atau benda yang menjadi pusat perhatian bagi peneliti. Dengan kata lain populasi adalah himpunan keseluruhan objek yang diteliti. Di dalam penelitian ini yang menjadi populasi adalah pengunjung atau pengguna situs Badan Pusat Statistik Provinsi Sumatera Selatan.

\subsubsection{Sampel}

Sedangkan sampel adalah bagian dari jumlah dan karakteristik yang dimiliki oleh populasi (Sugiyono, 2011:62). Oleh karena itu sampel harus memberikan gambaran yang baik tentang populasi, karena dengan pengambilan sampel tersebut akan mewakili gambaran dari keseluruhan populasi. Menurut Jogiyanto (2008) sampel yang baik adalah sampel yang akurat dan juga tepat. Karena sampel yang tidak tepat dan akurat akan memberikan kesimpulan penelitian yang tidak diharapkan atau dapat memberikan hasil kesimpulan yang salah. Untuk menentukan besarnya sampel dalam penelitian ini ditentukan dengan menggunakan rumus Lemeshow, dikarenakan pengunjung situs Badan Pusat Statistik yang bersifat umum sehingga jumlah populasinya tidak diketahui atau tidak terhingga. Berikut ini adalah rumus Lemeshow:

$$
\frac{\mathrm{n}=\mathrm{Z}^{2} \cdot \mathrm{P}(1-\mathrm{P})}{\mathrm{d}^{2}}
$$

Sumber: Sugiyono (2014:166) 
Keterangan:

$n=$ ukuran sampel

$Z=$ skor z pada kepercayaan 95\% $(1,96)$

$p=$ maksimal estimasi $(0,5)$

$d=$ alpha $(0,10)$ atau sampling error $=10 \%$

Melalui rumus diatas maka jumlah sampel yang diambil adalah:

$\mathrm{n}=1.962 \cdot 0.5(1-0.5) / 0.12$

$\mathrm{n}=3.8416 \cdot 0.25 / 0.01$

$n=0.9604 / 0.01 n=96$

\subsection{Variabel Penelitian}

Variabel adalah suatu atribut yang atau sifat atau nilai dari orang, objek atau kegiatan yang mempunyai variasi tertentu yang ditetapkan oleh peneliti untuk dipelajari dan kemudian ditarik kesimpulannya (Sugiyono, 2013: 38). Berikut ini adalah variabel di dalam penelitian ini:

Tabel 1. Variabel Penelitian

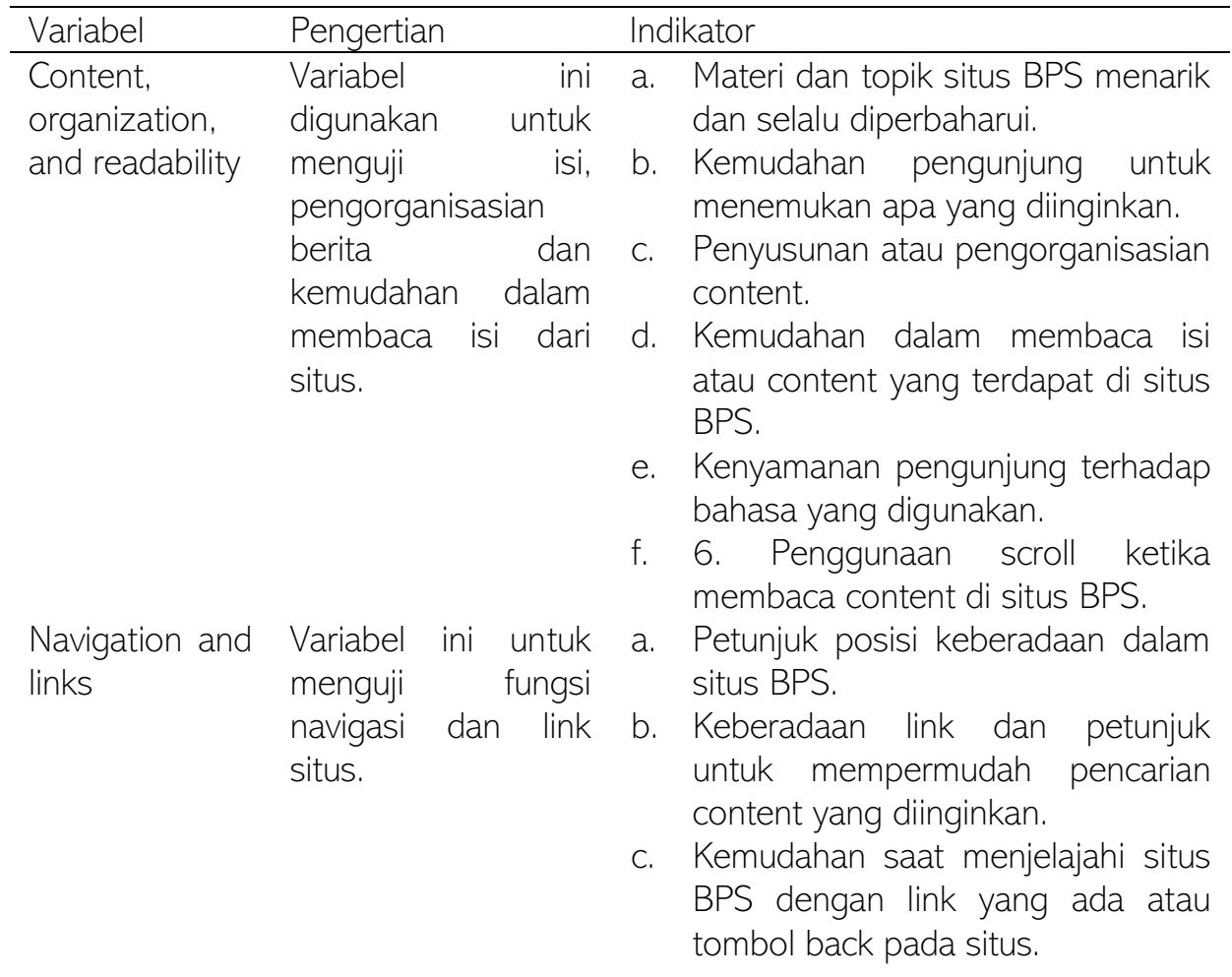




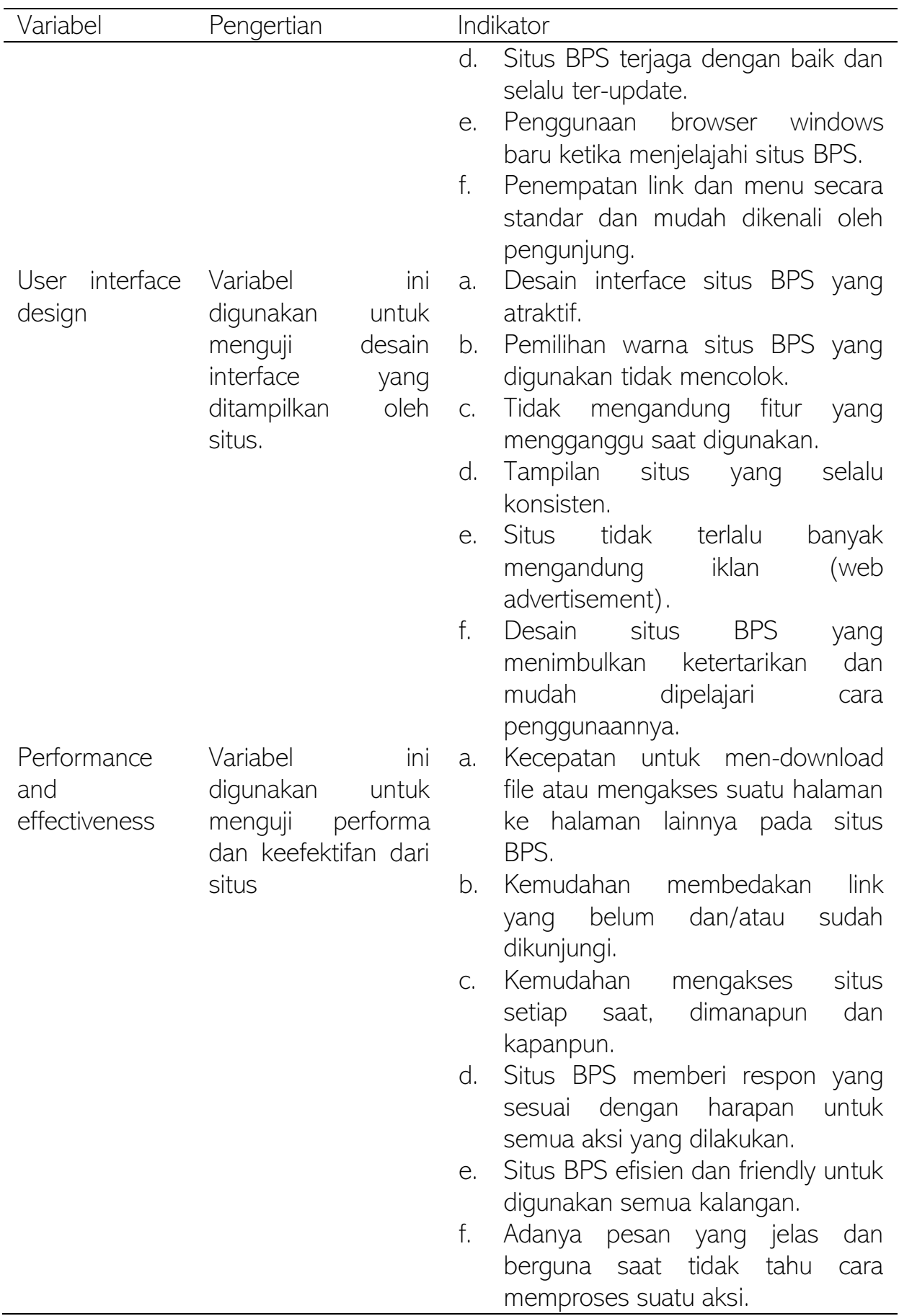




\subsection{Tahapan Penelitian}

Tahapan penelitian merupakan langkah demi langkah dalam penyusunan Tugas Akhir mulai dari proses pengumpulan data hingga pembuatan dokumentasi Tugas Akhir (Wahono, 2007).

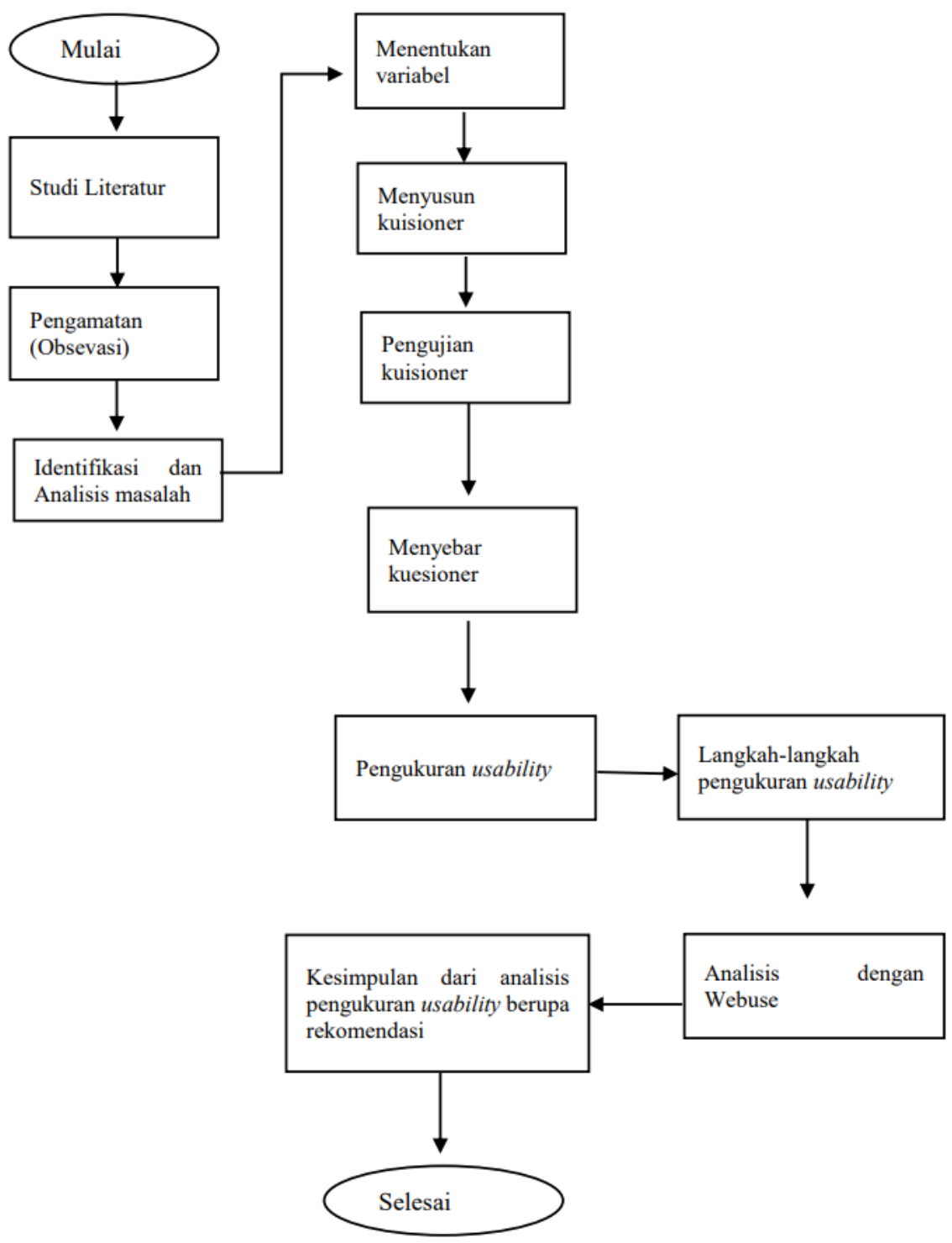

Gambar 2 Tahapan Penelitian 


\section{HASIL DAN PEMBAHASAN}

\subsection{Deskripsi Responden}

Responden Berdasarkan Jenis Kelamin, Data pribadi responden yang diisi pada saat pengisian kuesioner salah satunya adalah data jenis kelamin yang dapat dilihat pada tabel di bawah ini.

\section{Tabel 2 Responden Berdasarkan Jenis Kelamin.}

\begin{tabular}{ccc}
\hline Jenis Kelamin & Jumlah & Persentase \\
\hline Laki-Laki & 46 & $48 \%$ \\
Perempuan & 50 & $52 \%$ \\
Total & 96 & $100 \%$ \\
\hline
\end{tabular}

Berdasarkan tabel di atas jenis kelamin responden laki - laki yang mengisi kuesioner berjumlah 46 orang dengan persentase $48 \%$ dan jenis kelamin responden perempuan sebanyak 50 orang dengan persentase $52 \%$

\subsection{Hasil Penelitian}

1) Variabel Content, Organization, and Readability

\section{Variabel Content, Organization, and Readability}

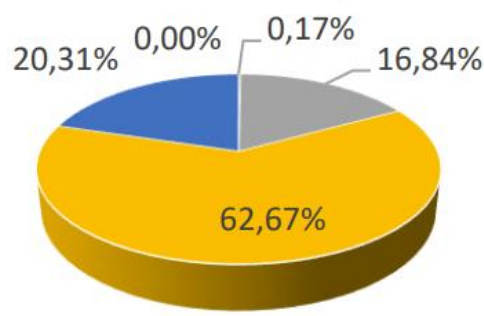

- Sangat Tidak Setuju - Tidak Setuju " Netral = Setuju = Sangat Setuju

Gambar 3 Diagram Variabel Content, Organization, and Readability

Berdasarkan diagram diatas didapatkan persentase hasil responden yang menjawab sangat tidak setuju sebesar $0 \%$, tidak setuju sebesar $0,17 \%$, cukup setuju sebesar $16,84 \%$, setuju sebesar $62,67 \%$ dan sangat setuju sebesar $20,31 \%$. 
Tabel 2 Poin Usability Variabel Content, Organization, and Readability.

\begin{tabular}{clc}
\hline No & \multicolumn{1}{c}{ Pernyataan } & $\begin{array}{c}\text { Jumlah } \\
\text { Merit }\end{array}$ \\
\hline 1 & Materi dan topik situs ini menarik dan selalu diperbaharui. & 72,75 \\
2 & Saya dapat dengan mudah menemukan apa yang saya & 73,5 \\
3 & inginkan di situs ini. & 70,75 \\
4 & Kentent atau isi situs ini teroganisir dengan baik. & 71,75 \\
5 & situs ini. & 74,25 \\
6 & Saya merasa nyaman terhadap bahasa yang digunakan. & 73,5 \\
& memudahan penggunaan scroll kiri dan kanan ketika & 436,5 \\
& $\quad$ Total Merit & 72,75 \\
& Rata-rata Merit (Total Merit/Jumlah Pernyataan) & 0,76 \\
\hline
\end{tabular}

Pada tabel di atas dapat diketahui bahwa variabel Content, Organization, and Readability mempunyai total merit sebesar 436,5 , rata-rata merit 72,75 dan memiliki poin usability sebesar 0,76.

2) Variabel Navigation and Links

\section{Variabel Navigation and Links}

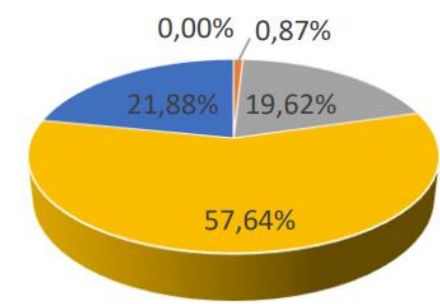

- Sangat Tidak Setuju = Tidak Setuju

- Netral $\quad$ Setuju

- Sangat Setuju

Gambar 4 Diagram Variabel Navigation and Links

Dari diagram diatas didapatkan persentase hasil responden yang menjawab sangat tidak setuju sebesar $0 \%$, tidak setuju sebesar $0,87 \%$, cukup setuju sebesar 19,62\%, setuju sebesar 57,64\% dan sangat setuju sebesar 21,88\%. 
Tabel 3 Poin Usability Variabel Navigation and Links

\begin{tabular}{|c|c|c|}
\hline No & Pernyataan & $\begin{array}{l}\text { Jumlah } \\
\text { Merit }\end{array}$ \\
\hline 1 & Petunjuk posisi keberadaan dalam situs BPS mudah dipahami. & 72,75 \\
\hline 2 & $\begin{array}{l}\text { Situs ini memberikan petunjuk dan tautan yang berguna bagi } \\
\text { saya untuk mendapatkan informasi yang diinginkan. }\end{array}$ & 71 \\
\hline 3 & $\begin{array}{l}\text { Mudah berpindah di situs ini dengan menggunakan tautan } \\
\text { atau tombol kembali. }\end{array}$ & 73 \\
\hline 4 & Tautan di situs ini dipelihara dan diperbaharui dengan baik. & 70 \\
\hline 5 & $\begin{array}{l}\text { Situs ini tidak membuka terlalu banyak jendela browser baru } \\
\text { ketika digunakan. }\end{array}$ & 72,75 \\
\hline \multirow[t]{4}{*}{6} & $\begin{array}{l}\text { Penempatan tautan dan menu secara standar dan mudah } \\
\text { dikenali. }\end{array}$ & 73,25 \\
\hline & Total Merit & 432,75 \\
\hline & Rata-rata Merit (Total Merit/Jumlah Pernyataan) & 72,13 \\
\hline & Poin Usability (Rata-rata Merit/Jumlah Responden) & 0,75 \\
\hline
\end{tabular}

Pada tabel di atas dapat diketahui bahwa variabel Navigation and Links mempunyai total merit sebesar 432,75, rata-rata merit 72,13 dan memiliki poin usability sebesar 0,75.

3) Variabel User Interfice Design

\section{Variabel User Interface Design}

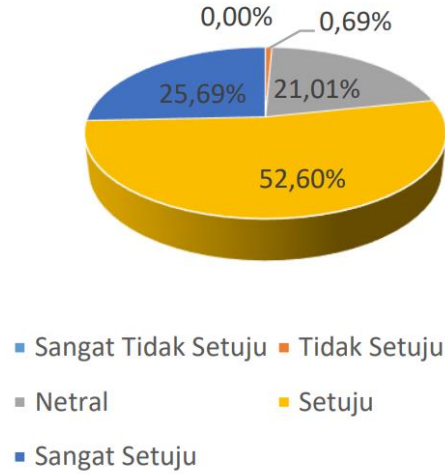

Gambar 5 Diagram Variabel User Interface

Design Dari diagram diatas didapatkan persentase hasil responden yang menjawab sangat tidak setuju sebesar 0\%, tidak setuju sebesar 0,69\%, cukup setuju sebesar $21,01 \%$, setuju sebesar $52,60 \%$ dan sangat setuju sebesar $25,69 \%$. 
Tabel 4 Poin Usability Variabel User Interface Design

\begin{tabular}{|c|c|c|}
\hline No & Pernyataan & $\begin{array}{l}\text { Jumlah } \\
\text { Merit }\end{array}$ \\
\hline 1 & Desain antarmuka situs ini menarik. & 71,5 \\
\hline 2 & $\begin{array}{l}\text { Saya merasa nyaman dengan warna yang digunakan di situs } \\
\text { ini. }\end{array}$ & 75,75 \\
\hline 3 & Tidak mengandung fitur yang mengganggu saat digunakan. & 73 \\
\hline 4 & Situs ini memiliki nuansa dan tampilan yang konsisten. & 72 \\
\hline 5 & $\begin{array}{l}\text { Situs tidak terlalu banyak mengandung iklan (web } \\
\text { advertisement). }\end{array}$ & 71,75 \\
\hline \multirow[t]{4}{*}{6} & $\begin{array}{l}\text { Desain situs yang masuk akal dan mudah dipelajari cara } \\
\text { menggunakannya. }\end{array}$ & 72,75 \\
\hline & Total Merit & 436,75 \\
\hline & Rata-rata Merit (Total Merit/Jumlah Pernyataan) & 72,79 \\
\hline & Poin Usability (Rata-rata Merit/Jumlah Responden) & 0,76 \\
\hline
\end{tabular}

Pada tabel di atas dapat diketahui bahwa variabel User Interface Design mempunyai total merit sebesar 436,75, rata-rata merit 72,79 dan memiliki poin usability sebesar 0,76.

4) Variabel Performance and Effectiveness

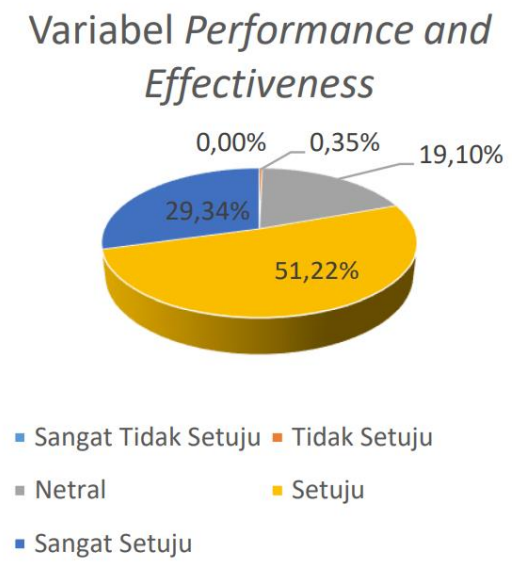

Gambar 6 Diagram Variabel Performance and Effectiveness

Dari diagram diatas didapatkan persentase hasil responden yang menjawab sangat tidak setuju sebesar $0 \%$, tidak setuju sebesar 0,35\%, cukup setuju sebesar 19,10\%, setuju sebesar 51,22\% dan sangat setuju sebesar 29,34\%. 
Tabel 5 Poin Usability Variabel Performance and Effectiveness

\begin{tabular}{|c|c|c|}
\hline No & Pernyataan & $\begin{array}{c}\text { Jumlah } \\
\text { Merit }\end{array}$ \\
\hline 1 & $\begin{array}{l}\text { Saya tidak menunggu terlalu lama untuk mengunduh file atau } \\
\text { membuka halaman. }\end{array}$ & 71,25 \\
\hline 2 & $\begin{array}{l}\text { Saya dapat dengan mudah membedakan antara tautan yang } \\
\text { sudah dikunjungi dan yang tidak dikunjungi. }\end{array}$ & 73,25 \\
\hline 3 & Saya dapat mengakses situs ini hampir setiap saat. & 76,25 \\
\hline 4 & $\begin{array}{l}\text { Situs ini memberi respon yang sesuai dengan harapan untuk } \\
\text { semua aksi yang dilakukan. }\end{array}$ & 75,5 \\
\hline 5 & Situs ini efisien dan friendly untuk digunakan semua kalangan. & 77,5 \\
\hline 6 & $\begin{array}{l}\text { Situs ini memberikan pesan yang jelas dan berguna ketika } \\
\text { saya tidak tahu bagaimana melanjutkan. }\end{array}$ & 72 \\
\hline & Total Merit & 445,75 \\
\hline & Rata-rata Merit (Total Merit/Jumlah Pernyataan) & 74,29 \\
\hline & Poin Usability (Rata-rata Merit/Jumlah Responden) & 0,77 \\
\hline
\end{tabular}

Berdasarkan tabel di atas dapat diketahui bahwa variabel Performance and Effectiveness mempunyai total merit sebesar 445,75, rata-rata merit 74,29 dan memiliki poin usability sebesar 0,77.

\subsection{Pembahasan}

Berdasarkan masing-masing nilai poin usability yang diketahui pada setiap variabel maka selanjutnya dapat dihitung nilai mean value poin usability seperti pada tabel di bawah ini.

Tabel 6 Data Poin Usability Situs BPS Provinsi Sumatera Selatan

\begin{tabular}{ccc}
\hline No. & Variabel & Poin Usability \\
\hline 1 & Content, organization, and readability & 0,76 \\
2 & Navigation and links & 0,75 \\
3 & User interface design & 0,76 \\
4 & Performance and & 0,77 \\
& Total Poin Usability & 3,04 \\
\multicolumn{3}{c}{ Mean Value Poin Usability (Total Poin Usability /Jumlah } \\
Variabel & 0,76 \\
\hline
\end{tabular}

Berdasarkan nilai mean value poin usability maka selanjutnya dapat diketahui level usability situs Badan Pusat Statistik Sumatera Selatan berdasarkan tabel hubungan poin usability dan level usability di bawah ini. 
Tabel 7 Hubungan Poin Usability dan Level Usability

\begin{tabular}{cc}
\hline Poin $\mathrm{x}$ & Level Usability \\
\hline $0<=x<=0,2$ & Sangat Buruk \\
$0,2<=x<=0,4$ & Buruk \\
$0,4<=x<=0,6$ & Sedang \\
$0,6<=x<=0,8$ & Baik \\
$0,8<=x<=1,0$ & Sangat Baik \\
\hline
\end{tabular}

Berdasarkan tabel hubungan poin usability dan level usability diatas pada variabel content, organization, and readability nilai poin usability situs Badan Pusat Statistik Sumatera Selatan mendapatkan nilai keseluruhan pernyataan sebesar 0,76 sehingga level usability yang didapatkan variabel ini berada pada tingkatan baik $(0.6<=0,76<=0.8)$. Pada variabel navigation and links nilai poin usability situs Badan Pusat Statistik Sumatera Selatan mendapatkan nilai keseluruhan pernyataan sebesar 0,75 sehingga level usability yang didapatkan variabel ini berada pada tingkatan baik $(0.6<=0,75<=0.8)$. Pada variabel user interface design nilai poin usability situs Badan Pusat Statistik Sumatera Selatan mendapatkan nilai keseluruhan pernyataan sebesar 0,76 sehingga level usability yang didapatkan variabel ini berada pada tingkatan baik $(0.6<=0,76<=0.8)$. Pada variabel performance and effectiveness nilai poin usability situs Badan Pusat Statistik Sumatera Selatan mendapatkan nilai keseluruhan pernyataan sebesar 0,77 sehingga level usability yang didapatkan variabel ini berada pada tingkatan baik $(0.6<=0,77<=0.8)$. Sedangkan untuk nilai mean value poin usability keseluruhan situs Badan Pusat Statistik Sumatera Selatan berada di posisi $0.6<=0,76<=0.8$. Sehingga dapat disimpulkan bahwa situs Badan Pusat Statistik Sumatera Selatan memiliki level usability di tingkatan baik menurut hasil penelitian yang didapatkan datanya dari 96 responden yang berbeda sebagai sampel.

\section{KESIMPULAN}

Berdasarkan hasil penelitian yang dilakukan pada bab sebelumnya didapatlah kesimpulan sebagai berikut:

1) Variabel content, organization, and readability nilai poin usability situs Badan Pusat Statistik Sumatera Selatan mendapatkan nilai keseluruhan pernyataan sebesar 0,76 sehingga level usability yang didapatkan variabel ini berada pada tingkatan baik.

2) Variabel navigation and links nilai poin usability situs Badan Pusat Statistik Sumatera Selatan mendapatkan nilai keseluruhan pernyataan sebesar 0,75 sehingga level usability yang didapatkan variabel ini berada pada tingkatan baik. 
3) Variabel user interface design nilai poin usability situs Badan Pusat Statistik Sumatera Selatan mendapatkan nilai keseluruhan pernyataan sebesar 0,76 sehingga level usability yang didapatkan variabel ini berada pada tingkatan baik.

4) Variabel performance and effectiveness nilai poin usability situs Badan Pusat Statistik Sumatera Selatan mendapatkan nilai keseluruhan pernyataan sebesar 0,77 sehingga level usability yang didapatkan variabel ini berada pada tingkatan baik.

5) Nilai mean value poin usability keseluruhan situs Badan Pusat Statistik Sumatera Selatan berada di posisi $0.6<=0,76<=0.8$, sehingga dapat disimpulkan bahwa situs Badan Pusat Statistik Sumatera Selatan memiliki level usability di tingkatan baik menurut hasil penelitian yang didapatkan datanya dari 96 responden yang berbeda sebagai sampel.

\section{DAFTAR PUSTAKA}

Aynayya, Qurrota. Dkk. 2018. Evaluasi Usability dan Rekomendasi Perbaikan Tampilan Website Seleksi Mahasiswa (SELMA) Universitas Brawijaya. Malang, Vol 2, No 4 Maret 2018, ISSN: 2548-964X.

Chiew, T.K. \& Salim, S.S. 2003. Webuse: Website Usability Evaluation Tool. Malaysian Juornal of Computer Science. 6 (1), pp.45-57.

Dewi, luneike Kartika. Dkk. 2018. Analisis Usability Aplikasi Mobile Pemesanan Layanan Taksi Perdana Menggunakan Metode Webuse dan Heuristic Evaluation. Malang, Vol. 2, No. 8, Agustus 2018. ISSN: 2548-964X.

Jogiyanto HM., MBA., Akt., Ph.D. 2005. Analisis \& DESAIN pendekatan tersruktur teori dan praktek aplikasi bisnis. ANDI. Yogyakarta.

Oktaviani. Nia. 2017. Analisa Website Media Elektronik Di Sumsel Melalui Penerapan Usability Pada Evaluasi Metode Webuse. Kediri, 22 Februari 2017, ISSN: 2549- 7952.

Sugiyono. 2015. Metode Penelitian Pendidikan (Pendekatan Kuantitatif, Kualitatif, dan R\&D), Bandung: Penerbit Alfabeta. 